International committee for

documentation and conservation

of buildings, sites and neighbourhoods of the

modern movement

Journal $44-2011 / 1$

\title{
Modern and Sustainable
}

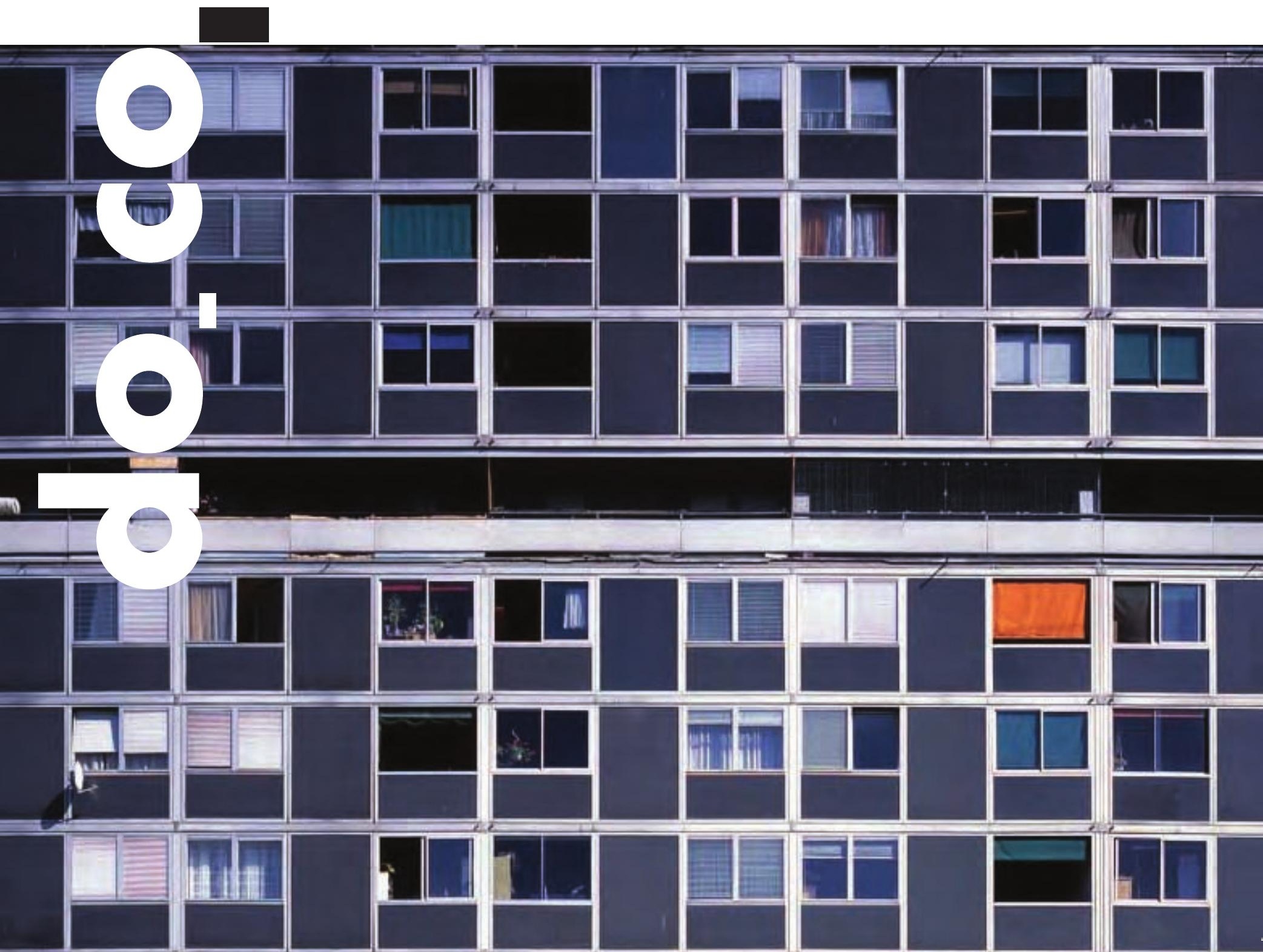




\section{Modern and Green:}

Heritige,

Energy,

Withe

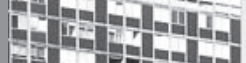

ing

然

E.

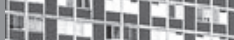

Thar

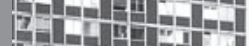

IT- -1

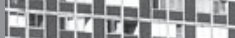

$\rightarrow-1+1-=$

-

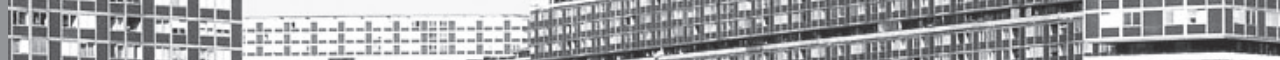

trin-1.-

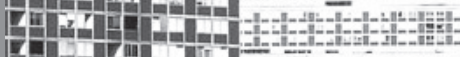

\section{$1-7 \ln 1$}

$x=-1-1$

Fin- -1

$4-1-1=$

24

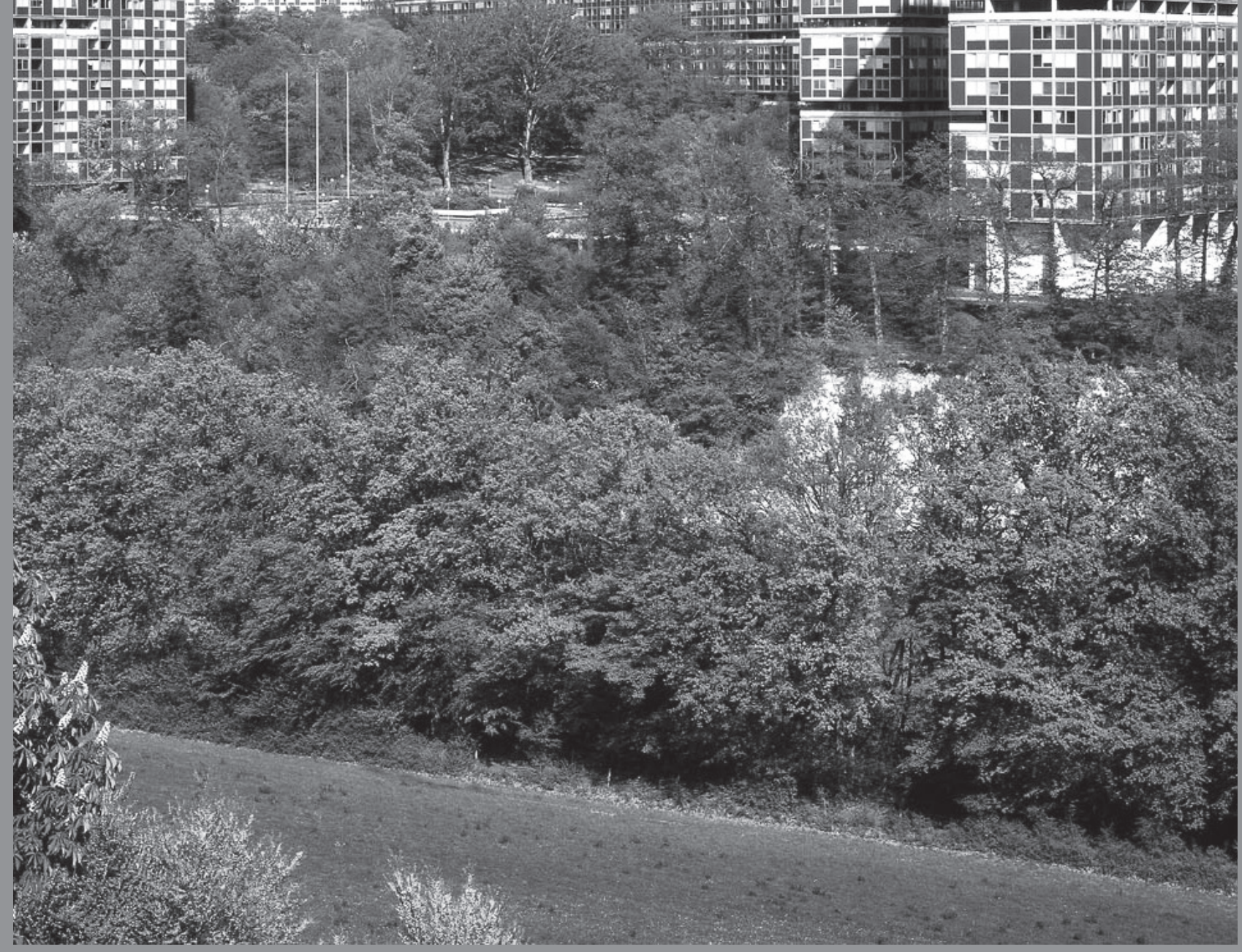
2 Dinting III 1 -1 I

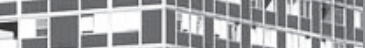

- II the

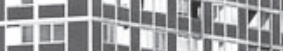
4 II 1 m -

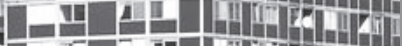
\begin{tabular}{|l|l|l|}
\hline & 1 \\
\hline
\end{tabular} in

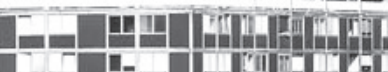
담

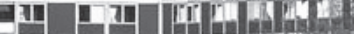
a $\mathrm{x}$ -

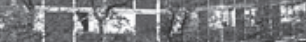

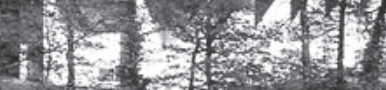
\#II

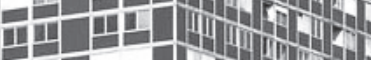
1 - menton 1 - 1400 -I 
$\mathrm{B}$ UILT between 1963 and 1971, the Lignon satellite precinct in Geneva (Georges Addor, Dominique Julliard, Louis Payot, Jacques Bolliger) is regarded as the most spectacular housing development in post-war Switzerland.

For some, it is an energy-guzzling black hole; for others, an historical monument. Either way, the Lignon has been in the spotlight. Faced with new imperatives to reduce energy consumption, a pilot project in the area of "conservation and thermal improvement" of the Lignon façades has been carried out by the Laboratory for Techniques and Preservation of Modern Architecture at the École Polytechnique Fédérale of Lausanne. The aim of this study is to introduce measures that will allow us to conserve the outer skin of the existing façades, while respecting energy standards, thereby guaranteeing the consistent level of intervention, across all 100,000 square meters of curtain walling, that the site deserves.

By Franz Graf and Giulia Marino

\section{Built Heritage and Energy Conservation}

$\mathbf{S}$ TATISTICS gathered by the Federal Bureau of Energy are revealing existing buildings account for some $40 \%$ of Switzerland's total energy consumption. On this evidence, improvements on energy performance in the building sector have been seen as a serious priority. There has been much talk about how we can potentially reduce consumption and $\mathrm{CO}_{2}$ emissions in buildings. In contrast, research has not yet come up with effective solutions to address the problem in relation to more "energy-hungry" sectors like transport. This explains the decidedly firm policies that exist in building rehabilitation, with ever more draconian rules, codes, and quality standards-such as the Minergie label-delivered by private organisations with the backing of major players in the building industry.

Under Switzerland's "2000 Watts Society" strategy, annual energy consumption targets for buildings after rehabilitation have shifted rapidly, not to say dramatically-permissible heating requirements falling threefold between 1988 and 2009.' There have been significant impacts on existing buildings. Architecture of the second half of the $20^{\text {th }}$ century, especially the one dating from the two decades that preceded the oil crises of the 1970s, has been a prime target. The specifics of construction (i.e. the material identity) of buildings of that era, widely regarded as leaky and poorly insulated, have made them especially vulnerable. Moreover, getting heritage recognition for these buildings has been no easy task; as a result, radical changes that show little regard for their architectural value and scant appreciation of the real potential afforded by adapting and altering them, have become all too common. Replacing envelopes, or adding external linings or wrapping them in insulation have been the order of the day. Contemporary heritage, far from being treated as a 'resource', has fallen victim to an unmitigated preference for introducing drastic measures for thermal improvement, regardless of a site's value as historical document and without adequate efforts to evalvate a building's actual performance.

For structures protected under heritage law-and for these only-the Recommendations on Improving Energy Consumption in Historic Monuments, drawn up jointly by the Federal Commission on Monuments and the Federal Bureau of Energy in 2009, recognise that "heritage and energy are both legitimate issues; they share essentially the same concerns and seek the same outcomes: supporting sustainable development by preserving non-replaceable natural and cultural resources". ${ }^{2}$ This important statement suggests that we need to develop "options and means that allow us to balance, on a case by case basis, the often diverging public interests that apply in these two areas, and to find constructive ways of resolving them" ${ }^{\prime \prime}$. This calls for a synthetic analysis that transcends what are widely seen as irreconcilable points of view. The research conducted by the Laboratory for the Techniques and Preservation of Modern Architecture at the École Polytechnique Fédérale of Lausanne on the envelopes of the Cité du Lignon in Geneva, a 1960s-era housing complex of recognised heritage value, has set out to do precisely this.

Over three years, from May 2008 to May 2011, the aim of the research was to define an ad hoc strategy for intervention, tailored to specific building needs, in order to see where improvements are needed and identify potential actions. The project on thermal improvements to curtain walling at the Lignon estate that came out of the research, was based on a scrupulous appraisal of these interests, facilitating the preservation of modern heritage by conserving existing material identity but also by saving energy. We show that by putting different measures in 
마 PA

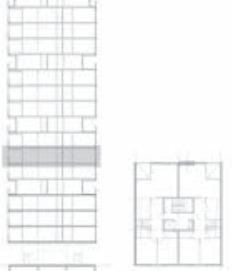

Enple

IPFI : sucurnum

26
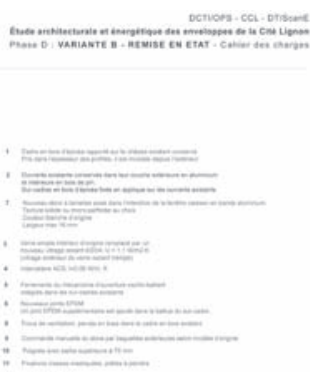

(")

$\because=$
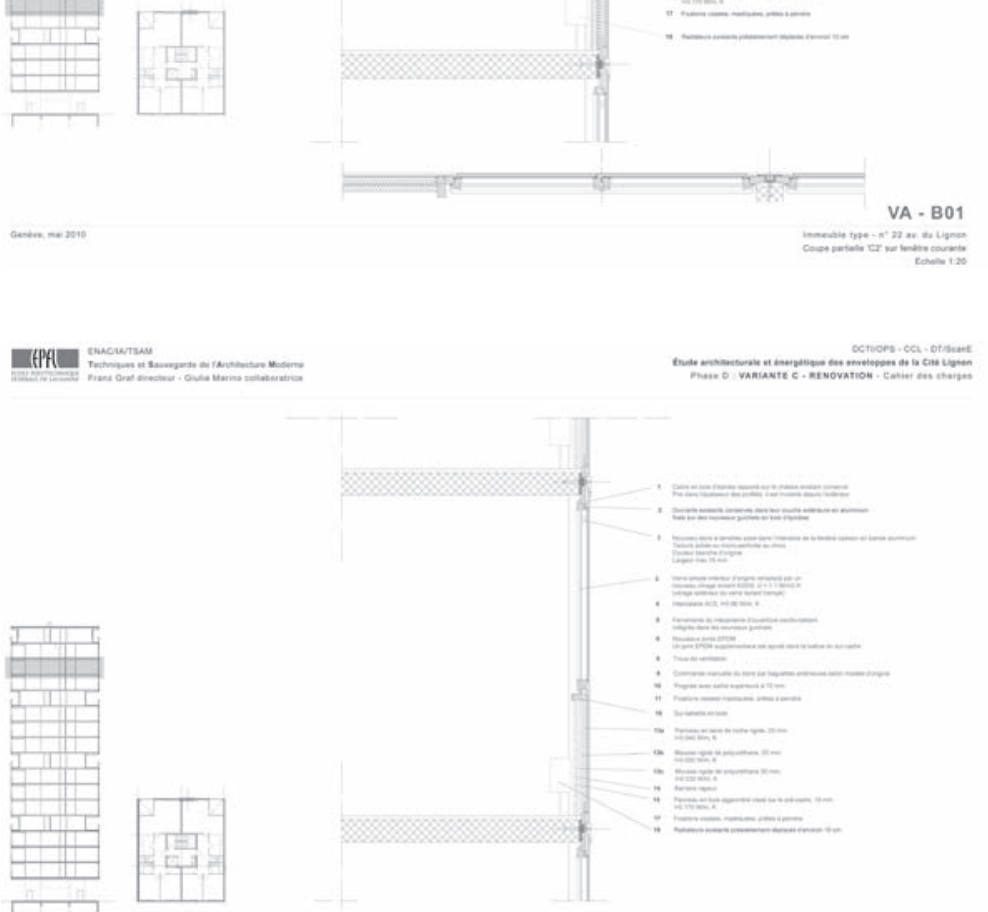

2 - 2 -
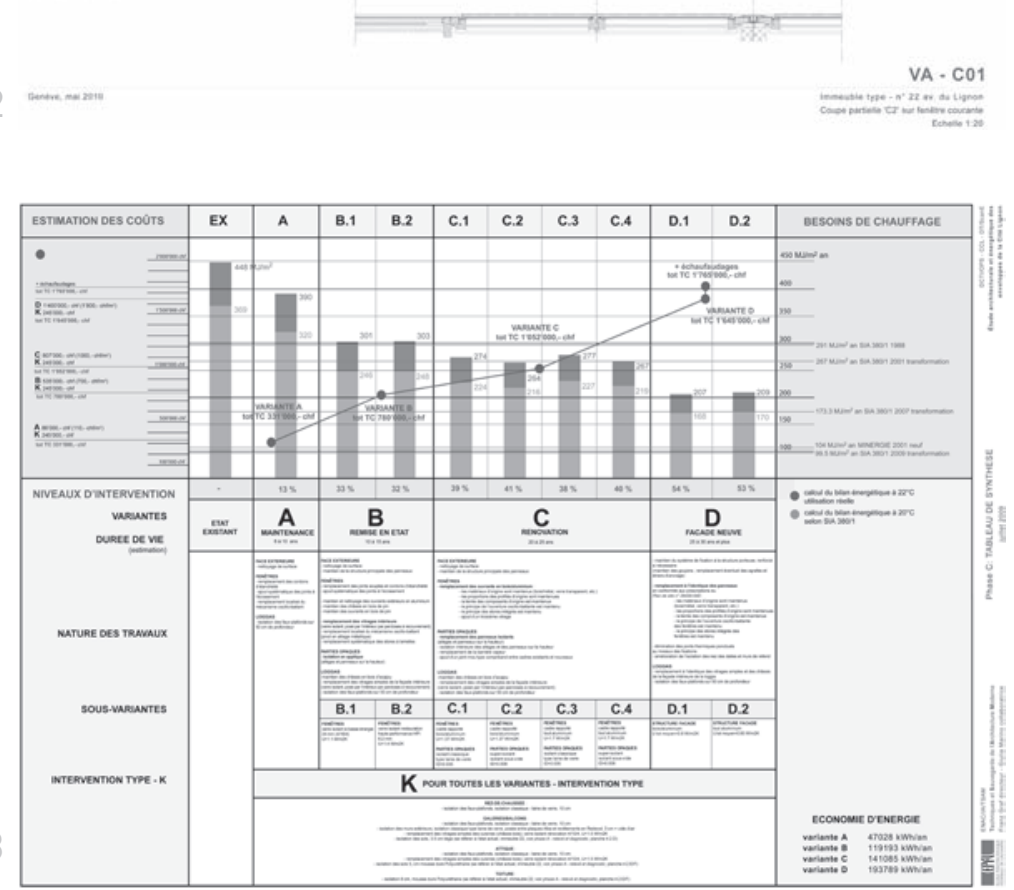
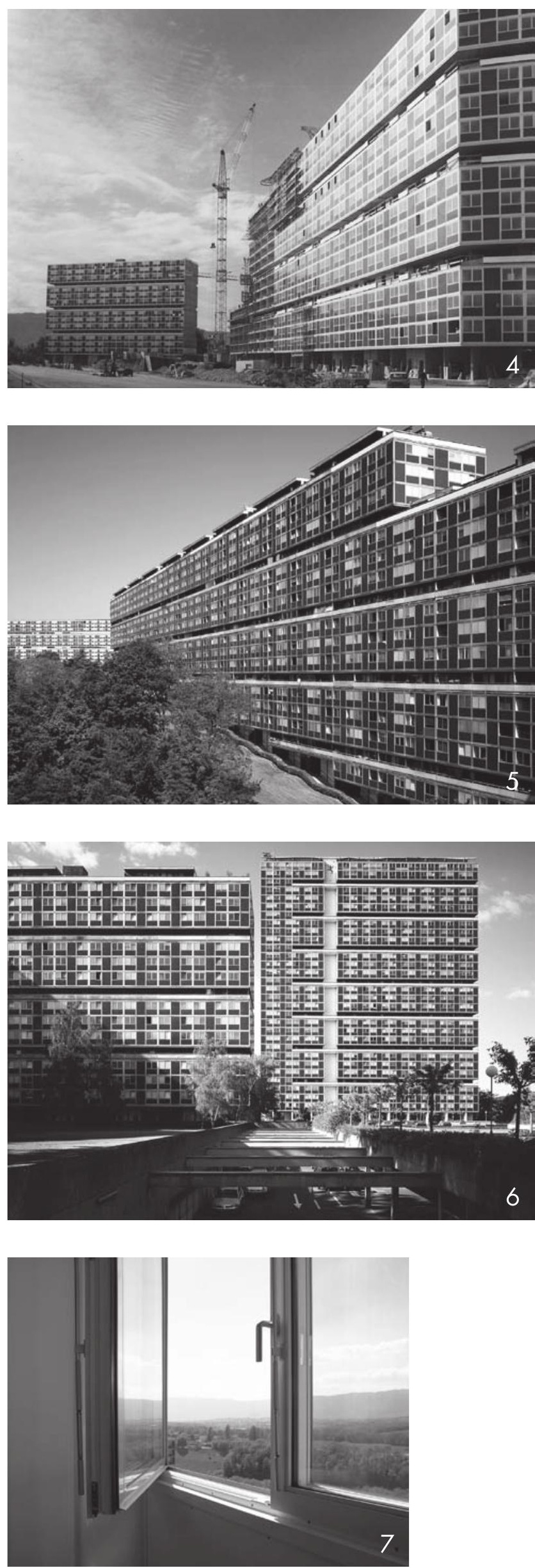
place, the conservation of existing envelopes can be assured in compliance with energy standards. By a method of evaluation that genuinely attempts to assess the issue using multiple criteria, based on exhaustive knowledge of the built object, its materiality and intrinsic characteristics, the study has yielded encouraging results that we hope will stimulate further efforts. We hope that, by focusing on a site as exceptional as the Lignon-which we will return to in more detail in the second part of this article-this kind of research may be of wider benefit to contemporary heritage and may go some way to addressing the negligence of recent years.

\section{La Cité du Lignon, Geneva}

Built between 1963 and 1971, the Cité du Lignon scheme was part of the Canton's strategy to tackle the population boom of the 1960s. It was an ambitious programme: a housing precinct-or "satellite city to use the vocabulary favoured at the time-for 10,000 people; 2,700 apartments (a disparate blend of residential forms, from subsidised rented units to condominium ownership), including extensive community facilities. The Geneva architecture firm led by Georges Addor was commissioned to design it. ${ }^{4}$

The Lignon was an exceptional scheme on several accounts: firstly, in terms of the layout. At the Meyrin satellite city ${ }^{5}$-the first of Switzerland's satellite housing estates-the same architects tested an alternative to the orthogonal grid-based urban plan with a discontinuous juxtaposition of the towers and ranges then favoured for new residential districts. At the Lignon, the principle is radically different: a free-standing block of 11 to 15 storeys forms a jagged, continuous line over one kilometre in length, defined by the perimeter and gradient of the plot; a pair of towers (of 26 and 30 floors respectively) at the far end of the plot conclude the arrangement and, together with community facilities occupying the central part of the site, completed the redevelopment of a site that would boast a building density of one square meter of floor space to one square meter of land.

As Eugène Beaudouin had suggested in 1955, the architects firmly rejected the idea of "splitting up unbuilt spaces with blocks facing one another, limiting outlook and casting shadows over each other". ${ }^{6}$ With a layout derived from a single continuous volume, George Addor in the 1960s allied himself with a strain of thought that openly rejected the strict application of Modernist doctrine. The project for the new town of Toulouse le Mirail, by Candilis, Josic and Woods, was certainly a point of reference, as shown by the earliest sketches for the Lignon, from 1962, where the "biological" model introduced by Alison and Peter Smithson (notably for the Berlin Haupstadt of 1958) is plainly visible.?

\section{The Rationalisation of Construction}

As Werner Heerde, engineer with the firm of Weisz, in charge of the Lignon project, put it: " $10,000 \mathrm{~m}^{3}$ of concrete $+10,000 \mathrm{~m}^{3}$ of concrete $+10,000 \mathrm{~m}^{3}$ of concrete doesn't just make $30,000 \mathrm{~m}^{3}$ of concrete: it also makes a unit that responds to new laws and demands a new approach". ${ }^{\circ}$

As well as the site layout, which, as we have seen, broke with convention and underlined the scheme's architectural modernity, this pioneering project also possesses remarkable technical and constructive features. The notions of industrialised building and rationalised structural systems-capital themes during the post-war decades of the Trente Glorieuses-were in fact central to the realisation. Faced with building on such a huge scale, the systems, components and details-everything from the structure of reinforced concrete leaves (the first use in Switzerland of the industrialised building process known as "tunnel formwork ${ }^{\prime \prime}$ ), to prefabricated curtain wall design-were devised so as to simplify the construction process.

If the load bearing frame cannot strictly be described as prefabricated (but rather as industrialised construction), the 125,000 square meters of façade curtain walling at the Cite du Lignon are perfectly in line with the principles of prefabrication, just as the architects claimed. ${ }^{10}$

They consist of large format panels $(2.80 \times 2.40$ and $2.80 \times 1.80$ meters), one full storey high, comprising a pinewood interior frame and aluminium exterior panel. The infill comprises alternating fixed, opaque elements (tempered glass with interior insulation) and glazed, opening (box-type) panels, the wooden inner and metal outer frames being separated."

Figure 1. EPFL-ENAC-IA-TSAM, defining possible levels of intervention, OPTION B - REHABILITATION window panel cross section, 1:20.

Figure 2. EPFL-ENAC-IA-TSAM, defining possible levels of intervention, OPTION C - REFURBISHMENT window panel cross section, 1:20

Figure 3. EPFL-ENAC-IA-TSAM, guidance table: cost estimates/levels of intervention/heating needs, June 2009.

Figure 4. Cité du Lignon, façade panel assembly. Photo by Ferronerie Genevoise SA. Figures 5, 6. Cité du Lignon. Photo by Claudio Merlini.

Figure 7. Prototype of the OPTION C - REFURBISHMENT, May 2010. Photo by Claudio Merlini. 
On such a large urban canvas, a search for volumetric and plastic development of continuous façades plays a primary role. The smooth exterior surface, accentuated by aluminium joinery, is enhanced by the subtle brilliance of glazing and modulated by alternating transparent and opaque infill elements. ${ }^{12}$

\section{Legal Protection and the Project Thermal Improvements to Exterior Envelopes}

"Le Lignon is an event; it is a Modern-age Place des Vosges or Place Vendôme. [...] In the repertory of Modern urban planning, the Lignon is the chapter on housing, [...] a classic both of architecture and of urbanism"13, wrote Pierre-A. Emery in 1969. Presented as Switzerland's most important post-war housing scheme, the Lignon has been widely seen by critics as remarkable on several levels: town planning, architectural, technical and social. An exceptional scheme both in scale and originality, the Cité du Lignon has been widely discussed, in Switzerland and abroad, mostly in glowing terms. The object of a number of sociological studies since the day it opened, the Lignon, described as "a well-loved giant", ${ }^{14}$ by the local press, is indeed much appreciated by its residents, who value its living environment.

The Cantonal heritage authorities also acknowledge the merit of Addor and Julliard's creation, and the Lignon is safeguarded by a Conservation Plan approved in May 2009,15 the aim of which is to put in place "specific measures aimed at preserving the architectural unity of the buildings, the planning design and the landscape quality of exterior spaces". 16

Although the Lignon's heritage value has been legally recognised, a total conservation strategy is needed. With no clear legal framework on the nature of interventions and faced with unauthorised replacement of features such as PVC windows in place of wood/metal frames, the Canton of Geneva and the consortium representing the building's owners commissioned the TSAM Laboratory in May 2008 to prepare an Architectural and Energy Study of the Envelopes. ${ }^{17}$

\section{Different Levels of Intervention and Synthesis of the Issues Involved}

Based on an exhaustive survey and diagnostic assessment of envelope constituents, ${ }^{18}$ and integrating an analysis of the thermal behaviour of a specimen block, four intervention options have been identified for standard Lignon façades. They have been ranked according to their impact on the material character of the building (i.e. conservation impact) and studied in terms of architectural and technical implications in the context of Conservation Plan stipulations (i.e. visual and physic-chemical impact on the original façade fabric).

They range from simple maintenance (option A), ${ }^{19}$ to replacement of curtain walling with a replica (option D), ${ }^{20}$ with intermediate solutions that include repair (option $\mathrm{B})^{21}$ and refurbishment (option C). ${ }^{22}$

To compare multiple criteria within these different options a guidance table was produced using three types of data: on the horizontal axis are descriptions of works to be carried out and life-cycle estimates. On the vertical axis, we show a summary assessment of costs ${ }^{23}$ and energy needs (including an estimate of the heating cost savings). ${ }^{24}$ The three variables, heritage, economy and energy are therefore easily visible at a glance. Looking at the table, which we see as a decision-making tool to assist building owners, one immediately rejects proposition D, façade replacement, for which the high overall cost cannot be justified in terms of any reduction in heating needs (which, at an annual consumption level of 207MJ/ $\mathrm{m}^{2}$, are above the legal limits prescribed under the new Swiss standard, SIA 380/1). Options A, B, and C are however retained: as well as ensuring acceptable conservation of the original façades, they offer a palette of possible interventions, all fully compatible with one another, from which owners can choose according to their financial means.

\section{Trials and Specifications}

During development of these options, an initial feasibility test showed clearly that standard solutions (off-theshelf Modern replacement windows) should be rejected, none being suitable in the context. Instead, a bespoke solution, applied over $100,000 \mathrm{~m}^{2}$ of façade and designed on an ad hoc basis, has to be preferred in order to meet the stipulations of the Conservation Plan. To this end, prototypes of the $A, B$ and $C$ options were planned for the complete exterior envelope of a specimen apartment, i.e. standard storey façades and a walkway front. ${ }^{25}$ Designs for façade detailing and assembly, and final selection of materials in terms of installation and thermal properties (tested not only by simulation but under real conditions) were developed with a façades engineer and specialist contractor. From this, a set of standard methods to be used for each of the solutions, together with specifications giving detailed descriptions of the intervention and basic working guidelines, could be drawn up.

The Canton's heritage and energy authorities signed up in advance to these models and developed a simpli-

Figure 8. Cité du Lignon. Photo by Big, ca. 1975.

(Archives Addor et Julliard, Geneva - AJ).

Figure 9. Cité du Lignon. Photo by Claudio Merlini. 

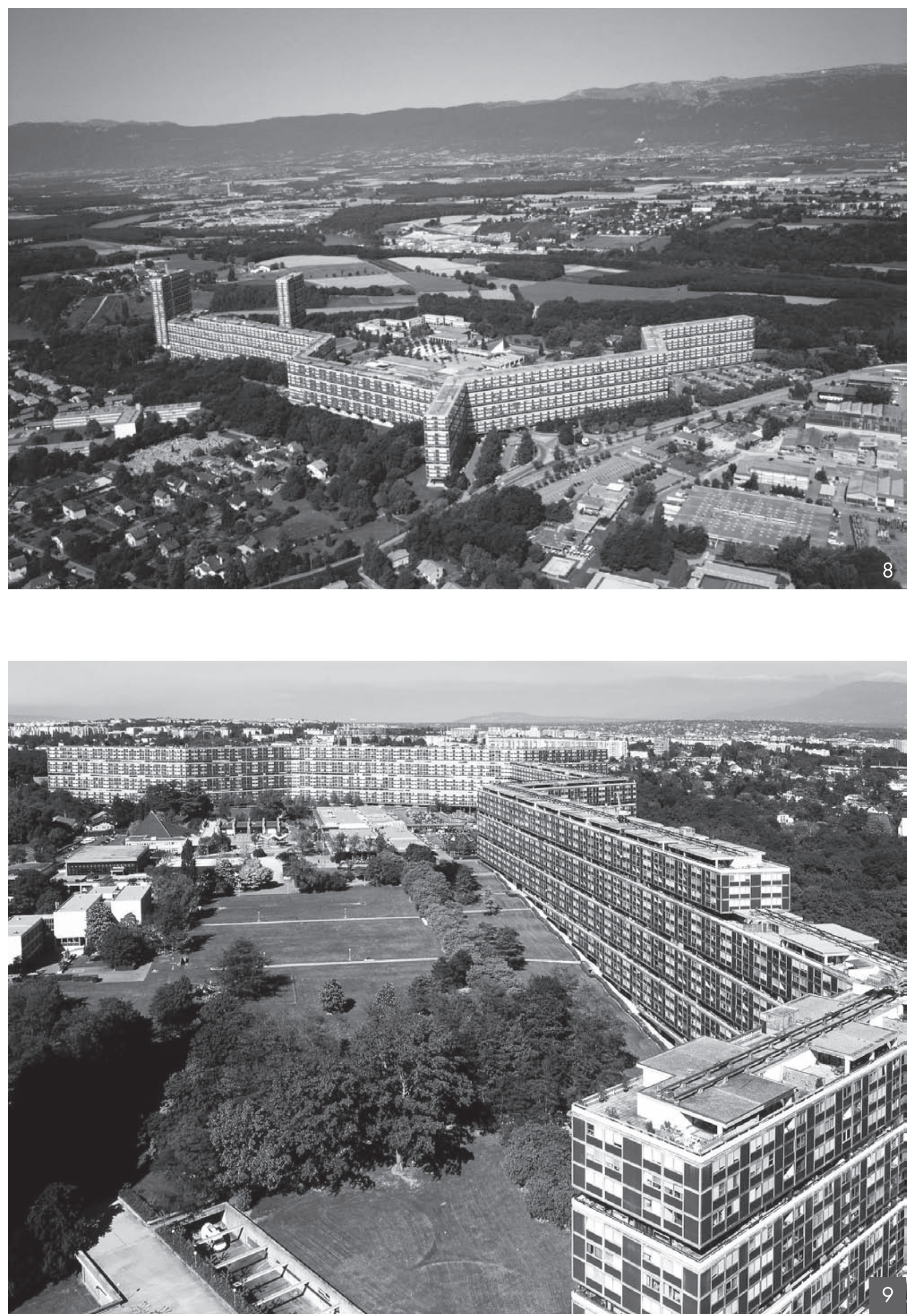
fied consent procedure. This allowed timely planning of works-essential at this scale-according to the means of building owners, and guaranteed an overall consistency in the works carried out, preserving the architectural unity of the Lignon site and its $120,000 \mathrm{~m}^{2}$ of façade envelopes.

\section{Le Lignon: Historic Monument or Run-of-the- mill Product?}

"Voracious", "energy black-hole", "ecological monster", the Lignon precinct has been called all manner of things in recent years, and widely denounced as a disaster in terms of sustainable development. Radical renovation of the site to bring it into compliance with current standards has been dismissed as fanciful. After three years of research, our study has produced encouraging results. A $70 \%$ improvement in overall energy consumption in relation to annual figures of $475 \mathrm{MJ} / \mathrm{m}^{2}$ (it is important to bear in mind that the building's consumption is now on a par with average consumption across the Canton) is now possible. That allows us to get close to, if not to actually within, legal limits (as is possible with the most radical options now available, using 'ultra high performance' materials like vacuum insulation, aero gels, 'Heat Mirror' glazing, etc.). ${ }^{26}$

We feel it is vital to emphasise that this can be done without circumventing current laws, even though the Lignon does enjoy a measure of protection in the form of a Conservation Plan. Off-setting energy consumption as demanded by local authorities can then become part of an energy saving strategy that, even though it may not always be enough to achieve statutory targets, nonetheless can yield excellent results broadly within legal limits.

The Cité du Lignon is exceptional in scale, originality and architectural quality. Its value as a monument is legally recognised through the adoption of a Conservation Plan for the site. It has merited nothing less than an exhaustive investigation, a pilot study spread over a fairly long period so that the most appropriate solutions for energy use mitigation can be established, fully respecting original material identity and taking proper account of the financial resources available to the various owners. Our study affords an opportunity to look more widely at large-scale contemporary heritage and its future. The convergence of heritage, economic constraints and energy issues calls for a global strategy, for specially designed, forward-looking preventive conservation tools to enable consistent legal frameworks to be developed. In terms of method, but also in terms of results, our pilot study could be a valuable precedent, applicable to a broader corpus of similar objects, not least to more routine examples of post-war building stock.
Notes

1. Refer to Swiss standards SIA 380/1, 1988 and 2009 version, for this shift.

2. Office Fédéral de l'Energie/Commission Fédérale des Monuments Historiques, Recommandations pour l'amélioration du bilan énergétique des monuments historiques, Berne, July 2009.

3. Ibid.

4. Architects Georges Addor and Dominique Julliard, who ran the firm, assisted in the design and execution phases by architects Jacques Bolliger and Louis Payot, the principal collaborators, along with Werner Francesco, Willy Rutz, Werner Wetz and Slobodan Vasiljevic. Heinz Weisz was project civil engineer, with Werner Heerde, project supervisor and Claude Budry, assistant. The remarkable exterior landscaping was by Walter Brugger.

5. Georges Addor, Jacques Bolliger and Louis Payot, architects, 1958 1964.

6. Beaudoin, Eugène, "De la composition des plans-masse des groupes d'habitations", Forum, n³, March 1955, 61-68: 68.

7. Interviews with assistants working in Addor's office, architects PingAn Chu (5 May 2011) and Werner Francesco (4 June 2011).

8. Heerde, Werner, "Industrialisation des grands ensembles locatifs", in Bulletin Technique de la Suisse Romande, n. 4, 24 February 1968, 47-52: 50 .

9. Used experimentally in France since the end of the 1950s, "tunnel formwork" was in a sense the logical descendant of table and shutter systems. It was based on using metal elements that allowed floors and thin walls to be cast simultaneously. Cf. Heerde, Werner, "Réduction important des délais d'exécution du gros œuvre dans le bâtiment-Utilisation d'un nouveau système de coffrage mis au point en France", in Bulletin Technique de la Suisse Romande, $n^{\circ} 13,24$ June $1972,221-224$

10. Development of the façade components was undertaken by the Geneva firms of Mangola SA (wood parts) and Ferronerie genevoise SA (metal parts), working in close partnership. The innovative panel design and project scale attracted the support of AluSuisse, who followed developments closely and tested the panels' bending resistance (under their own weight and under wind and suction effects), water tightness and stability in the wind tunnel at their Zurich research facility. Cf. Vögtlin, Rudolf, "Façades en bois et aluminium de la cité satellite 'Le Lignon' à Genève", Aluminium Suisse, n 17, March 1967, $59-65$.

11. The fruitful lessons Addor's practice learned during the Cité Meyrin commission some years before were repeated here with the same constructional system and materials. An unusual choice for a residential scheme (there are only a few examples internationally), their solution went further at Cité du Lignon in terms of façade continuity, identical on both the building's orientations.

12. Vasiljevic, Dobrila and Slobodan, "Grille dimensionnelle binaire du Lignon", Werk, n 5, May 1969, 322.

13. Émery, Pierre A., "La Cité du Lignon, Genève", Architecture, Formes, Fonctions, $n^{\circ} 15,1969,248-253: 248$.

14. Bezaguet, Laurence, "Site hors norme aimé des siens, Le Lignon devient un Monument", Tribune de Genève, 14 May 2009.

15. Canton de Genève, DCTI, Office du Patrimoine et des Sites, Service des Monuments et des Sites, Le Lignon-Commune de Vernier, Plan de site $n^{\circ}$ 29430-540, rationale, 5 August 2004. Decree, Conseil d'Etat 13 May 2009.

16. Ibid. Among the protection measures envisaged by the Cantonal law on protection of monuments and sites, the Plan de site is the one best suited to the Lignon. Owing to the scale and architectural character of the site, with its 7,000 inhabitants (and large number of owners) "rather than add the site to the National Inventory, a plan de site [Area Conservation Plan] in fact offers better scope for protecting the ensemble, given that buildings and landscape form an integrated whole".

17. The study was commissioned by the DCTI/Office du patrimoine et des sites/Service des monuments et des sites, the DT/Service de 
l'énergie-ScanE/ Energétique du bâtiment and thé Comité Central du Lignon, representing the interests of owners. Partners working with the EPFL-ENAC-TSAM were the Groupe Energie de I'Université de Genève, and the firms of Sorane rationalisation énergétique SA and BCS-façades

18. The building, effectively a 15-storey row, was redrawn at 1:50 and 1:20, showing plans, sections and frontage elevations, with later modifications colour coded according to a dedicated scheme lyellow-demolitions, red-additions). The standard curtain wall façade was then illustrated at a scale of 1:5 in vertical and horizontal cross section, at three representative points: opening panel, opaque panel and loggia. Its components were illustrated diagrammatically, with full descriptions.

19. Option A: improving air-and water-tightness of the façade by replacing waterproof caulking around existing panels and windows as well as the incorporation of pressure joints (not present in the originall.

20. Option D: exact replacement of curtain wall façade panels with replicas in timber and metal (full floor height), as well as loggia façades (joinery and glazing).

21. Option B: improvements to average thermal values by works to the inside face, notably fitting of insulation materials to the opaque units (spandrel panels and top panels), plus reglazing of standard plain interior window panels and loggias using secondary glazed panels fitted with a cover strips and modified wooden stops.

22. Option C: conservation (as in B) of the outer layer of the existing façade, and replacing the inner layer with new insulated glazing for opening lights and renewal of insulation (replaced with a more efficient insulating material) in opaque panels.

23. Costings for each option were produced in collaboration with specialist contractors. Four of the firms consulted estimated more economically from an architects' specification produced during the phase of definition of the nature of works. A total figure and an average ratio per $\mathrm{m}^{2}$ for the cost of the various interventions features on the left-hand vertical axis. Site constraints were also costed out

24.An assessment of thermal performance of the specimen block in its original state and simulations for the four options listed were made using EnerCad software. This software is recognised by the Federal Energy Bureau as a tool for calculating heat justification in buildings.

25. Envelopes at walkway level, as well as ground-floor entrance halls, were included in an addendum to the project on curtain walling. Carried out between May 2010 and May 2011, this last phase of study enabled a final calculation to be made of thermal performance and levels of consumption for a specimen building.

26. Using Superglass or similar glass products, annual heating consumption levels $\left(97 \mathrm{MJ} / \mathrm{m}^{2} /\right.$ year) are below the legal limit set by Swiss standard SIA 380/1 ver. 2009 (102 MJ/m²/year). Cheap quality standard insulated glazing units deliver an overall value slightly above the SIA $\left(111 \mathrm{MJ} / \mathrm{m}^{2} /\right.$ year). In an overall refurbishment context using solar energy installations to cover $30 \%$ of hot water needs for a household would yield a weighted consumption of $208 \mathrm{MJ} / \mathrm{m}^{2} /$ year, which is lower than the level needed to obtain the Minergie label $\left(216 \mathrm{MJ} / \mathrm{m}^{2} /\right.$ year $)$.

\section{References}

"Le Lignon", Habitation, Year 37, nº 9, September 1965, 35-36, 38-39 and front cover.

Vögtlin, Rudolf, "Façades en bois et aluminium de la cité-satellite 'Le Lignon' à Genève", Aluminium Suisse, n 17, March 1967, 59-65.

Heerde, Werner, "Le Lignon, eine Satellitenstadt in Genf", Schweizerische Bauzeitung, cahier n 52, December 1967, 320-324.

Heerde, Werner, "L'industrialisation dans les grands ensembles locatifsla cité nouvelle d'Onex-le Lignon", BTSR, n 4, 24 February 1968, 47-52.

Émery, Pierre-A., "La Cité du Lignon, Genève", Architecture, Formes, Fonctions, $n^{\circ} 15,1969,248-253$
Marchand, Bruno, "Inflexion vers l'architecture du territoire-La situation en Suisse romande dans les années soixante", Werk, Baven + Wohnen, $n^{\circ} 7 / 8$, August 2000, 36-43, 76-77.

EPFL-ENAC-TSAM, "Étude architecturale et énergétique des enveloppes de la Cité du Lignon (Genève, 1963-1971)", jointly commissioned by the Office du patrimoine et des sites - DCTI-Canton de Genève, ScanE-Service de l'Energie-DT-Canton de Genève and the Comité Central du Lignon, Franz Graf, research leader, Giulia Marino, research assistant, research report, 2008-2011.

Graf, Franz, Marino, Giulia Marino, "Heritage, energy, economy: planned preventive conservation and thermal improvements to building envelopes at the Cité du Lignon satellite precinct, Geneva (1963-1971)", Conserving Architecture-Planned Conservation of XX Century Architectural Heritage, international conference proceedings (Como, Italy, 30-31 October 2009), Milan, Electa, 2009, 216-227.

Huber, Werner, "Ein Superlatif wird saniert. Die Genfer Siedlung Le Lignon ist ein Riegel con einem Kilometer Länge. Beton, Glas und Alu sind in die Jahre gekommen", in Hochparterre, supplement to issue 6/7, 2011, 8-13.

Graf, Franz, Marino, Giulia, "Denkmalschutz und Energetische Sanierung des Cité du Lignon", in Arch+, n² 203, June 2011, 102-107.

\section{Franz Graf}

Has been an independent architect in Geneva since 1989 and is currently Professor of Construction at the Accademia di Architettura di Mendrisio (since 2005), and Associate Professor in Theory and Design at the École Polytechnique Fédérale de Lausanne, were he runs the Laboratory for Techniques and Preservation of Modern Architecture (TSAM) since 2007. His research focuses on the understanding of modern and contemporary structural systems and his publications have featured in major reference works on Perret (2002), Prouvé (2005), Viganò (2008), Mangiarotti (2010), and Honegger (2010).

\section{Giulia Marino}

Is an architect and graduate of the University of Florence. She obtained a higher degree in Conservation of Modern and Contemporary Built Heritage at the Institute of Architecture, University of Geneva, in 2006. A researcher at the Laboratory for Techniques and Preservation of Modern Architecture (TSAM) at the École Polytechnique Fédérale de Lausanne since 2005, she enrolled for a PhD in 2008 (with a thesis that deals with interior comfort, heating and air-conditioning systems in the architecture of the $20^{\text {th }}$ century). Her scientific interests lie in the field of history of 20th-century construction techniques and conservation/preservation of Modern and contemporary architecture. 
docomomo International is a non-profit organization dedicated to the documentation and conservation of buildings,

sites and neighborhoods of the modern movement. It aims at:

- Bringing the significance of the architecture of the modern movement to the attention of the public, the public authorities, the professionals and the educational community.

- Identifying and promoting the surveying of the modern movement's works.

- Fostering and disseminating the development of appropriate techniques and methods of conservation.

- Opposing destruction and disfigurement of significant works.

- Gathering funds for documentation and conservation.

- Exploring and developing knowledge of the modern movement.

docomomo International wishes to extend its field of actions to new territories, establish new partnerships with institutions, organizations and NGOs active in the area of modern architecture, develop and publish the international register, and enlarge the scope of its activities in the realm of research, documentation and education.

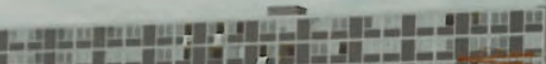
-

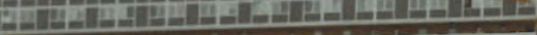

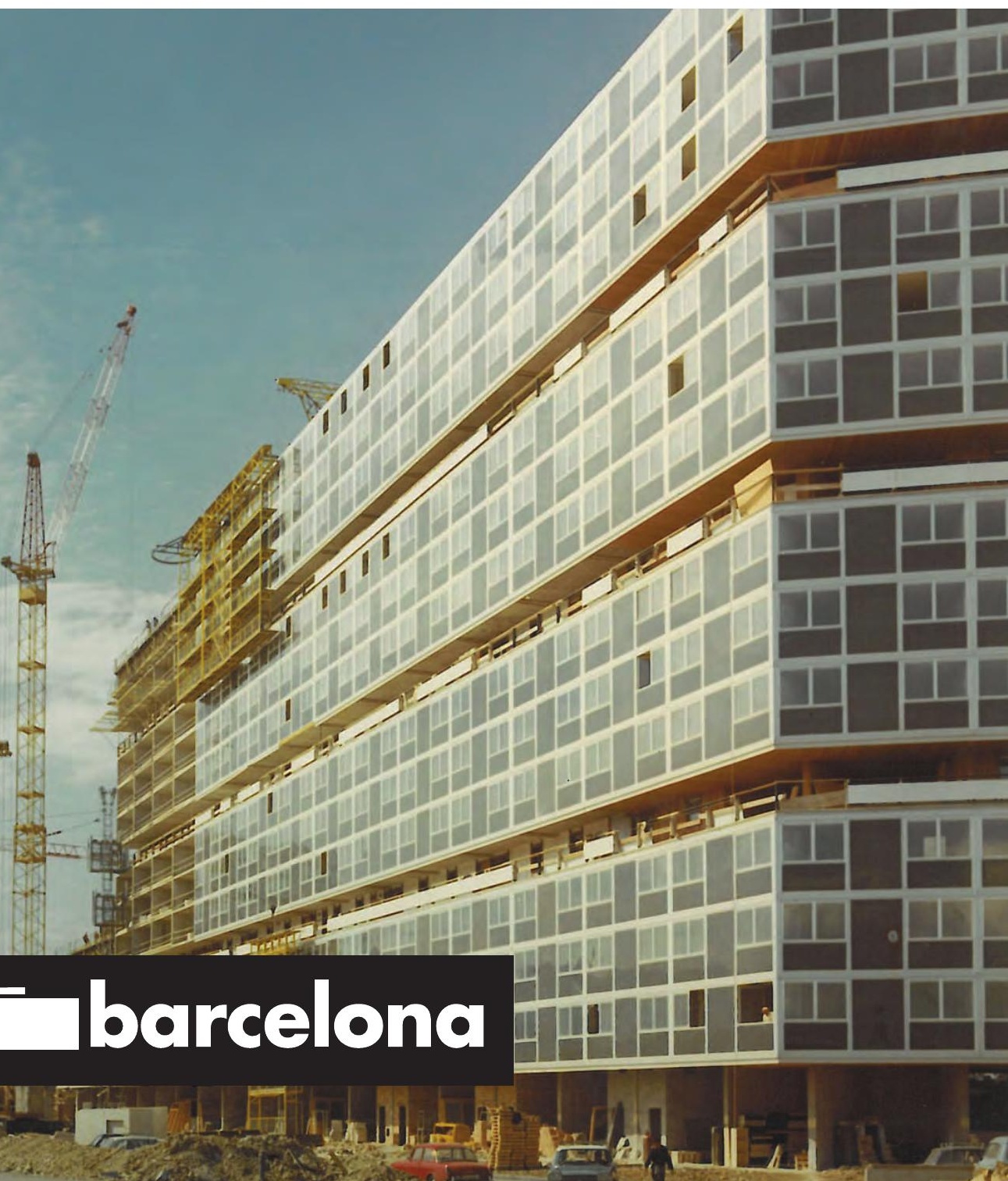

